Published in final edited form as:

J Cell Physiol. 2000 April ; 183(1): 1-9. doi:10.1002/(SICI)1097-4652(200004)183:1<1::AID-

$\mathrm{JCP} 1>3.0 . \mathrm{CO} ; 2-\mathrm{J}$.

\title{
Role of Insulin-Like Growth Factors and Their Binding Proteins in Growth Control and Carcinogenesis
}

\author{
Adda Grimberg ${ }^{1}$ and Pinchas Cohen ${ }^{2, *}$ \\ ${ }^{1}$ Division of Pediatric Endocrinology, University of Pennsylvania, Philadelphia, Pennsylvania \\ ${ }^{2}$ Division of Pediatric Endocrinology, UCLA, Los Angeles, California
}

\section{Abstract}

Interest in the role of the insulin-like growth factor (IGF) axis in growth control and carcinogenesis has recently been increased by the finding of elevated serum insulin-like growth factor I (IGF-I) levels in association with three of the most prevalent cancers in the United States: prostate cancer, colorectal cancer, and lung cancer. IGFs serve as endocrine, autocrine, and paracrine stimulators of mitogenesis, survival, and cellular transformation. These actions are mediated through the type 1 IGF-receptor (IGF-1R), a tyrosine kinase that resembles the insulin receptor. The availability of free IGF for interaction with the IGF-1R is modulated by the insulinlike growth factor-binding proteins (IGFBPs). IGFBPs, especially IGFBP-3, also have IGFindependent effects on cell growth. IGF-independent growth inhibition by IGFBP-3 is believed to occur through IGFBP-3-specific cell surface association proteins or receptors and involves nuclear translocation. IGFBP-3-mediated apoptosis is controlled by numerous cell cycle regulators in both normal and disease processes. IGFBP activity is also regulated by IGFBP proteases, which affect the relative affinities of IGFBPs, IGFs and IGF-1R. Perturbations in each level of the IGF axis have been implicated in cancer formation and progression in various cell types.

Recently, several case-control studies have associated elevated serum levels of insulin-like growth factor I (IGF-I) to increased risk for three of the most prevalent cancers in the United States, thereby causing an enhanced interest in the role of IGFs in growth control and carcinogenesis. Insulin-like growth factor-binding proteins (IGFBPs) modulate IGF action and also regulate cell growth and apoptosis in IGF-independent manners. Assessment of the impact of IGFBPs on cancer risk, therefore, has been addressed as well. Although these case-control studies provide an association and do not prove causality, the findings do prompt a closer inspection of IGF axis perturbations and carcinogenesis.

Prostate cancer, the most commonly diagnosed cancer in American men (Landis et al., 1998), has been shown repeatedly to relate to serum IGF-I levels (Grimberg and Cohen, 1999). Both a nested case-control study within the Harvard Physicians' Health Study (Chan et al., 1998) and a population-based case-control study in Sweden (Wolk et al., 1998) revealed a 7-8\% elevation in serum IGF-I levels among prostate cancer patients relative to

*Correspondence to: Pinchas Cohen, Division of Pediatric Endocrinology, Mattel Children's Hospital at UCLA, 10833 Le Conte Ave. MDCC 22-315, Los Angeles, CA 90095-1752. hassy@ mednet.ucla.edu. 
age-matched controls. Three earlier studies were too small to achieve statistical significance (Cohen et al., 1993a; Kanety et al., 1993; Ho and Baxter, 1997). A 28\% increase in serum IGF-I levels among prostate cancer patients was previously reported (Mantzoros et al., 1997) but this overestimation was likely due to IGFBP interference with the assay used; the higher IGFBP-2 levels found in prostate cancer (Cohen et al., 1993a; Kanety et al., 1993; Ho and Baxter, 1997) can compete with the radiolabeled IGF-I trace in the IGF-I radioimmunoassay after acid-ethanol extraction and thereby falsely elevate the measured IGF-I values (Cohen, 1998). The 7\%-8\% increment was determined by enzyme-linked immunoabsorbent assay (Chan et al., 1998) and immunoradiometric assay (Wolk et al., 1998), twoantibody methods that are less susceptible to IGFBP effects.

The association of prostate cancer with changes in serum IGFBP levels has had mixed results. Serum levels of IGFBP-2, the main IGFBP produced by prostate epithelial cells, were elevated relative to healthy age-matched controls and correlated with serum prostatespecific antigen levels and tumor stage (Cohen et al., 1993a; Kanety et al., 1993; Ho and Baxter, 1997). In contrast, serum levels of IGFBP-3, the major circulating carrier of IGF-I, were not different between prostate cancer patients and normal controls in one study (Cohen et al., 1993a) but reduced and negatively correlated with serum prostate-specific antigen in another (Kanety et al., 1993). Likewise, of the two most recent IGF case-control studies, one found an inverse relation between plasma IGFBP-3 levels and prostate cancer risk after controlling for IGF-I levels (Chan et al., 1998) whereas the other did not reveal a significant association between serum IGFBP-3 levels and cancer risk (Wolk et al., 1998).

Rates of colorectal carcinoma dramatically increased over the second half of this century and in the late 1970s began to decline in whites but continued to increase in African Americans (Troisi et al., 1999). Recently, a nested case-control study within the Harvard Physicians' Health Study comparing highest to lowest plasma quintiles in men revealed a 2.5 relative risk of colorectal cancer for IGF-I when controlled for IGFBP-3 and 0.28 for IGFBP-3 when controlled for IGF-I (Ma et al., 1999). Finding an increased incidence of gastric and colonic neoplasms has been inconsistent among acromegalics, who have elevated growth hormone, IGF-I, and IGFBP-3 levels (Klein et al., 1982; Barzilay et al., 1991; Ezzat and Melmed, 1991; Ron et al., 1991; Ladas et al., 1994).

Lung cancer incidence and mortality, in the antitobacco 1990's, have diminished in men but not in women (Wingo et al., 1999). An on-going hospital-based case-control study detected a dose-dependent association between plasma IGF-I levels and lung cancer risk (odds ratio 2.06), and a negative relation of lung cancer risk to IGFBP-3 levels when adjusted for IGF-I (odds ratio 0.48) (Yu et al., 1999).

\section{Igf-I and Mitogenicity}

IGF I and II, named for their primary structural homology to proinsulin, were isolated and sequenced in 1978 (Rinderknecht and Humbel, 1978a,b). Most of the circulating IGFs are produced by hepatocytes in response to growth hormone stimulation (Arany et al., 1994; Chin et al., 1994; Olivecrona et al., 1999). More than $90 \%$ of the circulating IGFs are bound to IGFBP-3 and the acid labile subunit to form a 150-kDa complex; IGFs are also carried by 
other IGFBPs, and less than $1 \%$ circulate in the free form (Baxter, 1994). The $150-\mathrm{kDa}$ complex serves to prolong the serum half-life of IGF-I from about $10 \mathrm{~min}$ to about $15 \mathrm{~h}$ (Guler et al., 1989) and to prevent the hypoglycemic effects of free IGFs (Baxter and Daughaday, 1991).

In addition to their endocrine functions, IGFs play important paracrine and autocrine roles in many tissues (Cohen and Rosenfeld, 1995). The single-copy sixexon IGF-I gene is transcribed from two promoters (P1 and P2), located $5^{\prime}$ to exons 1 and 2, respectively, resulting in RNAs with different $5^{\prime}$ leader sequences; alternative RNA splicing and differential polyadenylation yield multiple mature transcripts (Rotwein, 1991). Thus, modulation of gene transcription, usage of either promoter and transcription initiation site, alternative RNA splicing, and changes in mRNA stability allow IGF-I gene expression to be cell or tissue-specific, ontogeny-determined, or regulated by a number of different factors. In addition to stimulating hepatic IGF-I gene transcription, growth hormone can act on local IGF-I expression outside the liver. For example, growth hormone stimulates IGF-I gene transcription in mouse Ob1771 preadipocyte cells, and IGF-I further induces IGF-I production and cellular differentiation into adipocytes in an autocrine/paracrine fashion (Doglio et al., 1987; Kamai et al., 1996). Other hormones, such as estrogen, can affect IGF-I expression. No consensus estrogen-responsive element has been identified in IGF-I promoters but studies with chicken IGF-I gene P1 promoter have pointed to AP-1 enhancer as a mediator of estrogen responsiveness (Kajimoto et al., 1998). Time- and dose-dependent induction of IGF-I gene expression by estradiol treatment has been observed in a human fetal osteoblast cell line (Kassem et al., 1998). Osteoblast IGF-I mRNA levels are also increased by cyclic adenosine monophosphate (cAMP) (McCarthy et al., 1990) and transforming growth factor- $\beta$ (TGF- $\beta$ ) (Okazaki et al., 1995), and decreased by glucocorticoids (Swolin et al., 1996). Nutritional status also impacts IGF-I production. Hepatic IGF-I expression is decreased by fasting (Lowe et al., 1989), protein restriction (Straus and Takemoto, 1990) and/or energy restriction (Straus and Takemoto, 1991). Lower serum IGF-I levels were found in patients with anorexia nervosa (Stoving et al., 1999).

IGFs exert their actions by binding to the IGF receptors. The type 2 IGF receptor is identical to the man-nose-6-phosphate receptor and serves to clear IGF-II from the circulation (Ludwig et al., 1996) and inhibit autocrine/paracrine IGF-II actions (Ellis et al., 1996). The type 1 IGF receptor (IGF-1R), in contrast, is a tyrosine kinase resembling the insulin receptor and mediates the growth-promoting actions of both IGF-I and IGF-II (Ullrich et al., 1986). Signaling pathways for the IGF-1R include the insulin receptor substrate (IRS) family of proteins, Shc leading to the Ras/Raf/MAP kinase cascade, and Crk (Le Roith et al., 1998).

The IGF-1R effects several growth-promoting functions. IGF-1R stimulates mitogenesis in many different cell types, a function localized to the $\mathrm{C}$ terminal domain of the $\beta$ subunit (Esposito et al., 1997; Hongo et al., 1996). Mice carrying null mutations of IGF-1R died of respiratory failure at birth, were $45 \%$ of normal size, had generalized organ hypoplasia, developmental delays in ossification, and abnormalities in the central nervous system and epidermis (Liu et al., 1993). Null mutant mouse embryos for IGF-I, IGF-II, and IGF-1R, alone or in combination, revealed early IGF-1R mitogenic signaling for IGF-II only but for 
both IGF-I and IGF-II starting on embryonic day 13.5 (Baker et al., 1993). Another IGF-1R function is cellular protection from apoptosis, which is conferred by tyrosine residues 1250 and 1251 and histidine 1293 and lysine 1294 in the $C$ terminus of the $\beta$ subunit (Chen et al., 1998; O'Connor et al., 1997). Overexpression of IGF-1R in different cell models protected them against apoptosis-inducing agents (Resnicoff et al., 1995; D'Ambrosio et al., 1997; Dews et al., 1997; Prisco et al., 1997), and a dominant-negative IGF-1R mutant induced extensive apoptosis in vivo and inhibited growth in vitro (D'Ambrosio et al., 1996). The third function of IGF-1R is cellular transformation. Replacement of tyrosine residues 1250 or 1251 of the IGF-1R reduced anchorageindependent cell growth and disrupted the actin cytoskeleton and cellular localization of vinculin (Blakesley et al., 1998). Mouse embryo fibroblast cell lines with disrupted IGF-1R genes (IGF-1 $\mathrm{R}^{-/-}$) grew more poorly than wildtype, and were resistant to transformation by simian virus 40 large $\mathrm{T}$ antigen; transfection with human IGF-1R restored the transformed phenotype (Sell et al., 1993). Thus, not only can IGF-1R overexpression transform cells, but IGF-1R seems necessary for transformation by other agents.

\section{IGFBPS: Modulating IGF Actions}

Six IGFBPs with high affinity to IGFs have been identified, and four other molecules with low affinity have been described (IGFBP-related peptides) (Ferry et al., 1999). Of the highaffinity IGFBPs, the first five preferentially bind IGF-I over IGF-II, but IGFBP-6 has a 100fold higher affinity for IGF-II versus IGF-I (Baxter and Saunders, 1992). The distinctive binding properties of IGFBP- 6 may be due to its lack of two of the 12 conserved N-terminal cysteines which results in different $\mathrm{N}$-terminal disulfide linkages as determined by electrospray ionization mass spectrometry (Neumann and Bach, 1999). IGFBP-3 is the most abundant IGFBP in postnatal serum, and is produced primarily by hepatic endothelia and Kupffer cells (Arany et al., 1994; Chin et al., 1994). By forming the 150-kDa complex with IGFs, IGFBP-3 modulates the amount of bioavailable free IGF and inhibits its transfer from the circulation to tissue sites of action (Ballard et al., 1991).

All IGFBPs have growth-inhibitory effects by competitively binding IGFs and preventing their binding to the IGF-IR. Des-(1-3)-IGF-I, an IGF-I analogue that binds IGF-IR and stimulates DNA synthesis but does not bind IGFBP-3, has proven a useful tool in demonstrating this phenomenon. IGFBP-3 inhibited cellular proliferation induced by IGF-I but not by des-(1-3)-IGF-I in the human promyeloid cell line HL-60 (Li et al., 1997) and in transfected ishikawa endometrial cancer cells that overexpressed both IGF-IR and cell membrane-bound IGFBP-3 (Karas et al., 1997). IGFBP-3 also inhibited estradiol production by human granulosa cells in culture stimulated by follicle stimulating hormone and IGF-I but not by des-(1-3)-IGF-I (Barreca et al., 1996). Physiologically, IGF-I mediates follicle stimulating hormone-dependent inhibin expression and steroidogenesis throughout the development of ovarian dominant follicles, whereas IGFBP-4 and IGFBP-5 produced by granulosa cells inhibit these effects and lead to atresia of nondominant follicles (Erickson et al., 1998). IGFBP inhibition of IGF-I action has also been implicated in disease pathogenesis. For example, human osteoarthritic chondrocytes produced more IGF-I than normal chondrocytes, but demonstrated an even greater increase in IGFBP-3 and IGFBP-5 (Olney et al., 1996). 
Although IGFBP sequestration of IGFs from the IGF-1R is usually inhibitory, IGFBPs can enhance IGF effects by presenting and slowly releasing IGF-I for receptor interactions while protecting the receptor from down regulation by high IGF-1 exposure (Conover and Powell, 1991). This phenomenon has been shown for IGFBP-1, IGFBP-3, and IGFBP-5. Concentrations of IGFBP-1 that can inhibit the binding of IGF-I to its receptor sometimes augmented IGF-stimulated thymidine incorporation, depending on the target cell (Koistinen et al., 1990). In the absence of exogenously added IGFBP-1, IGF-I analogues with reduced IGFBP-1 affinity were more potent than IGF-I in stimulating DNA synthesis by porcine aortic smooth muscle airway cells; with simultaneous IGFBP-1 exposure, the IGF-I analogues had only 40\%-65\% of the maximal IGF-I response (Clemmons et al., 1990). Relative affinity for the IGF-1R versus the binding protein has also been proposed to contribute to IGFBP-3 enhancement of IGF-I function. Preincubation of fibroblasts with IGFBP-3 followed by its removal potentiated IGF-I effects on DNA synthesis in a dosedependent fashion and resulted in proteolyzed IGFBP-3 fragments bound to the cell membrane (Conover et al., 1993). Addition of IGFBP-3 to conditioned media in the same cell system, however, caused inhibition of cell growth (DeMellow et al., 1988). IGFBP-3 fragments bound to the cell membrane have an order of magnitude lower affinity for IGF-I than does intact soluble IGFBP-3, which has higher affinity for IGFs than to IGF-IR, and IGF-I has a lower affinity for the membrane-bound IGFBP-3 fragments than for the IGF-1R. Likewise, IGFBP-5 potentiation of IGF-I action in bone cells requires IGFBP-5 to be bound to the cell membrane or extracellular matrix; IGFBP-5 bound to the extracellular matrix has lower affinity for IGF-I but a prolonged half-life than does free IGFBP-5 (Andress and Birnbaum, 1992; Jones et al., 1993). Thus, in all three cases, the relatively lower affinity IGFBP-binding may serve as a reservoir of IGF-I that is readily released to the IGF-1R that has been saved from downregulation.

\section{IGFBPs: IGF-Independent Actions}

Aside from its IGF-dependent actions, IGFBP-3 has also been shown to inhibit growth in an IGF-independent fashion (Fig. 1). IGF-1R knockout mouse fibro-blasts, when transfected with a vector containing the IGFBP-3 gene, demonstrated growth inhibition that correlated with the magnitude of the IGFBP-3 expression (Valentinis et al., 1995). A rhIGFBP-3 fragment, with negligible binding affinity for IGF-I and presumably none for insulin, inhibited insulin-stimulated and IGF-I-stimulated DNA synthesis in chick embryo fibroblasts (Lalou et al., 1996). The same fragment also inhibited mitogenesis in murine fibroblasts with a defective IGF-IR that could respond to bFGF but not IGF, epidermal growth factor, nor platelet-derived growth factor (Zadeh and Binoux, 1997). The IGFindependent growth inhibition of IGFBP-3 occurs through the induction of apoptosis by IGFBP-3, as shown in IGF-IR knockout murine fibroblasts (Valentinis et al., 1995; Rajah et al., 1997).

IGF-independent IGFBP-3 effects are believed to be mediated by specific cell surface IGFBP-3 association proteins or receptors. The first evidence for such receptors consisted of specific, dose-dependent binding of IGFBP-3 to breast cancer cell surface proteins of 20, 26, and $50 \mathrm{kDa}$. In these estrogen-receptor-negative breast cancer cells, the growth-inhibitory effects of IGFBP-3 were shown to be dose-dependent and diminished by coincubation with 
IGFs but not by IGF analogues with reduced affinity for IGFBP-3 (Oh et al., 1993a,b). The mid-region of the IGFBP-3 molecule was recently identified as the site responsible for binding to these breast cancer cell surface receptors (Yamanaka et al., 1999). Similarly, specific IGFBP-3 association proteins were detected in cell lysates (18 to $150 \mathrm{kDa}$ ) and membrane fractions $(18,67$, and $150 \mathrm{kDa})$ of the prostate cancer cell line PC-3. The addition of exogenous IGFBP-3 to PC-3 cells resulted in a dose-dependent increase in the apoptotic index that was only partially attenuated by the addition of IGF-I and unchanged by the addition of IGF analogues with reduced affinity to IGFBP-3 (Rajah et al., 1997). A protein biochemically identified as the type V TGF- $\beta$ receptor (by affinity cross-linking and immunoprecipitation techniques) was shown to bind IGFBP-3, and it may be another IGFBP-3 association protein (Leal et al., 1997). However, this protein has not been characterized structurally or molecularly, and its size is several-fold larger than other putative IGFBP-3 receptors. IGFBP-3 has also been shown to interact with numerous molecules that may regulate IGFBP-3 action on cells (Hodgkinson et al., 1995), including transferrin (Weinzimer et al., 1999), type 1a collagen (Liu et al., 1999), heparin (Yang et al., 1996), and the latent TGF- $\beta$ binding protein (LTBP-1) (Xu and Murphy, 1998). IGFBP-3 interactions are not limited to endogenous molecules, however. Using several methods, we have shown that IGFBP-3 binds and interacts with the human papilloma virus oncoprotein E7 (Mannhardt et al., 1999), a phenomenon that may play a role in malignant transformation.

IGFBP-3 and IGFBP-5 have recently been shown to be translocated into the nucleus, compatible with having a nuclear localization sequence (NLS) in their mid-region (Jacques et al., 1997; Schedlich et al., 1998; Wraight et al., 1998). IGFBP-3 has also been shown to bind importin, a molecule that facilitates nuclear transport (Noll et al., 1997). The retinoid $\mathrm{X}$-receptor was just identified as an IGFBP-3-binding protein, and treatment with retinoic acid drives the IGFBP-3/RXR complex into the nucleus (Liu et al., 1999). Nuclear IGFBP-3 may directly control gene expression and play a role in the IGF-independent actions of IGFBP-3.

\section{Regulation Of IGF and IGFBP Actions}

IGFBP-3-mediated apoptosis is controlled by a number of cell cycle regulators. Using specific antisense oligonucleotides and neutralizing anti-IGFBP-3 antibodies to block IGFBP-3 expression and action, IGFBP-3 was identified as the mediator of apoptosis induced by retinoic acid and TGF- $\beta$ in multiple cell types (Erondu et al., 1996; Gucev et al., 1996; Han et al., 1997; Rajah et al., 1997). MCF-7 human breast cancer cells treated with retinoic acid had induction of IGFBP-3 transcription, mediated through retinoic acid receptor- $\beta$, and modulation of IGF-I-induced growth stimulation (Shang et al., 1999). MCF-7 cells treated with estradiol had suppression of IGBP-3 and enhanced proliferation; treatment with an antiestrogen agent had the opposite effects, and an IGFBP-3 anti-sense oligomer abolished the antiestrogen-induced growth inhibition (Huynh et al., 1996). TGF- $\beta$ and epidermal growth factor treatment reduced the amount of IGFBP-3 secreted by human keratinocytes in culture (Edmondson et al., 1999), so regulation of IGFBP-3 is both regulator- and cell type-specific. 1,25-dihydroxyvitamin D3 induced IGFBP-3 expression and growth inhibition in a nontumorigenic cervical cell line (Agarwal et al., 1999). cAMP 
was found to both increase IGFBP-3 gene transcription and stabilize IGFBP-3 mRNA in the Madbin Darby bovine kidney cell line (Erondu et al., 1999). The tumor suppressor p53 was found to induce IGFBP-3 expression by DNA-specific binding (Buckbinder et al., 1995). p53-mutants that lost the ability to activate IGFBP-3 and Bax could not induce apoptosis (Friedlander et al., 1996; Ludwig et al., 1996). We have shown that p53 induced IGFBP-3 and apoptosis in two neoplastic cell models which allowed direct manipulation of p53 levels (Grimberg et al., 1999).

IGFBP actions can also be modulated by IGBP proteases. IGFBP proteolysis was first described in pregnancy serum as proteolytic activity against IGFBP-3, and prostate-specific antigen (PSA) in seminal plasma was the first IGFBP protease to be biochemically identified (Cohen et al., 1992). The specific cleavage site of urinary PSA has recently been localized to tyrosine-159 of IGFBP-3 (Okabe et al., 1999), and prekallikrein binds the heparin binding domain of IGFBP-3 to form a protease/substrate complex before it cleaves (Durham et al., 1999). To date, proteolysis of IGFBP-2 to -6 has been described in multiple clinical states and cellular systems.

IGFBP proteases fall into three major categories. Kallikrein-like serine proteases which cleave IGFBP-3 include PSA, gamma-nerve growth factor (Rajah et al., 1996a), and plasmin (Angelloz-Nicoud et al., 1996; Booth et al., 1999). Thrombin, another serine protease, cleaves IGFBP-5 at physiologically relevant concentrations, i.e., within one order of magnitude of fibrinogen (Zheng et al., 1998). The second major category, cathepsins, are intracellular proteinases that activate under acidic conditions and may therefore play a role in certain physiological and pathological processes such as neoplastic infiltration (Conover et al., 1993, 1995; Nunn et al., 1997). Matrix metalloproteinases (MMPs or matrixins) comprise a family of peptide hydrolases that function in tissue remodeling by degrading extracellular matrix components such as collagen and proteoglycans. MMPs require a metal ion for their catalytic activity, so they are susceptible to inactivation by both metal chelators and specific inhibitors. MMPs have been identified in prostatic fluid and cells as well as other physiological and pathological tissues (Fowlkes et al., 1994a, 1994b; Rajah et al., 1996b).

Proteolytic activity may play a role in normal and abnormal tissue proliferation by cleaving IGFBPs into fragments with lower affinity for IGFs; these fragments allow increased levels of free IGFs to activate IGF-1Rs (Blat et al., 1994; Rajah et al., 1996b;). For example, PSAgenerated IGFBP-3 fragments have decreased affinity for IGFs, and prostatic epithelial cells grown in the presence of PSA demonstrate reversal of the inhibitory effects of IGFBP-3 on IGF-stimulated cell growth (Cohen et al., 1994). IGFBP proteases are also important autocrine/paracrine growth regulators, and there may be a short-loop for control of IGF activity. The IGFBP-3 protease secreted by MCF-7 breast cancer cells can be inhibited by IGFs (Salahifar et al., 1997), and an IGFBP-4 protease can be inhibited by IGFBPs but stimulated by IGFs (Donnelly et al., 1996; Fowlkes et al., 1997). Such findings suggest that the relative proportion of IGFs to IGFBPs can affect IGFBP protease activity, which in turn will modulate IGF/IGFBP/IGF-1R interactions. 


\section{IGFS and IGFBPs In Carcinogenesis}

Perturbations in each of the forementioned levels of the IGF axis have been implicated in cancer formation and progression in various cell types (Grimberg et al., 1998). A comprehensive review would be too exhaustive, so examples will be used instead. In essence, changes which raise the balance of IGF/IGF-1R activity versus IGFBP function can potentially contribute to carcinogenesis (Table 1).

IGF/IGF-1R activity can be escalated by increasing the amount of IGF or by enhancing IGF-1R function. Although there are now multiple reports of an association between higher serum IGF-1 concentrations and cancer risk, as described in the introduction, these associations do not prove causality. Higher serum IGF-1 concentrations may represent spillage from local autocrine/paracrine overproduction, which would actually be the primary event, or they may cause ascertainment bias in cancer diagnosis by causing symptomatic benign overgrowth (Colao et al., 1999; Grimberg and Cohen, 1999). Lowering serum IGF-I levels by diet restriction in p53-deficient mice with urothelial pre-neoplasia increased apoptotic rates and decreased tumor progression, an effect that was reversible by IGF-I treatment of similarly restricted mice (Dunn et al., 1997). Thus, the role of elevated systemic IGF-1 levels in carcinogenesis remains an intriguing possibility that needs to be investigated further. Elevated local IGF levels, from autocrine or paracrine overproduction, has clearly been implicated in neoplasia, however. For example, during prostate cancer progression in the transgenic adenocarcinoma of mouse prostate (TRAMP) model, which closely mimics prostate cancer progression in humans, prostate-specific IGF-I (but not IGF-II) mRNA expression increased and was elevated in the accompanying metastatic lesions (Kaplan et al., 1999).

IGF-1R activity can be augmented either as a direct consequence of increased receptor number and/or function or as a result of enhanced receptor stimulation by more bioavailable IGF. An example of the former is the improved growth of tamoxifen-resistant breast cancer cells when greater IGF-1R levels were induced by estradiol treatment, and the inhibition of their growth by IGF-1R monoclonal antibody (Parisot et al., 1999). More IGF can become bioavailable to stimulate the IGF-1R due to diminished IGFBP sequestration; this may be achieved by either reduced IGFBP production and/or by increased IGFBP proteolysis. For example, when Caco-2 human colon carcinoma cells were stably transfected with an IGFBP-3 cDNA expression construct, they achieved a much lower final cell density after one-and-a-half weeks of growth and began transcription of sucrase-isomaltase, a marker of enterocyte differentiation; in Caco-2 cells transfected with empty plasmid, IGFBP-3 was undetectable, growth was unimpaired, and sucrase-isomaltase was not produced (MacDonald et al., 1999). Increased proteolysis of IGFBP-3 has been shown in prostate cancer by PSA (Cohen et al., 1992), cathepsin D (Nunn et al., 1997), urokinase and plasminogen-activator (Angelloz-Nicoud and Binoux, 1995). Finding a negative correlation between serum IGFBP-3 levels and prostate (Kanety et al., 1993), colon (Ma et al., 1999) and lung (Yu et al., 1999) cancer risk suggests a protective role against the effects of systemic IGF-I. 
Diminished IGFBP bioactivity can also contribute to carcinogenesis by loss of the IGFindependent effects on growth inhibition and apoptosis. It is unknown what degree of systemic IGFBP-3, if any, participates directly in IGF-independent cell growth regulation. Changes in local IGFBP-3 levels from autocrine/paracrine effects do play a role in carcinogenesis, however. Again, the lower IGFBP levels may be the result of decreased production or increased proteolysis. Decreased autocrine/paracrine production of IGFBP-3 may reflect an impairment in IGFBP-3 induction by various hormones, cytokines, or cell cycle regulators. For example, treatment of glioblastoma multiforme cells with a PKCaselective antisense oligonucleotide led to induction of p53, IGFBP-3, and apoptosis but not $\mathrm{Bcl}-\mathrm{X}_{\mathrm{L}}$, Bax or $\mathrm{p} 21 \mathrm{WAF}^{\text {, }}$, three other p53-response molecules (Shen et al., 1999). In addition, diminished IGFBP-3 bioactivity may be found in the future to result from primary defects in its cell surface association proteins or receptors or in its nuclear localization, once these processes are more thoroughly characterized.

Thus, alterations in the IGF/IGFBP balance have been shown, at different levels and in various models, to contribute to carcinogenesis. The recent associations of increased cancer risk with elevated circulating IGF concentrations do not prove causality. But given the fact that IGF axis changes often play a role in carcinognesis, the contribution of systemic IGF levels must be further investigated.

\section{Acknowledgments}

This work was supported by NIH Grants 2RO1 DK47591, 1P50 HL 56401, and 1RO1 AI40203 (P.C.); CaP CURE and ACS Research Awards (P.C.); The Lawson Wilkins Pediatric Endocrine Society Lilly Fellowship Award (A.G.); and fellowship grants from Eli Lilly \& Co. and Pharmacia-Upjohn (A.G.).

Contract grant sponsor: NIH; Contract grant numbers: 2RO1 DK47591, 1P50 HL 56401, and 1RO1 AI40203; Contract grant sponsor: CaP CURE and ACS Research Awards; Contract grant sponsor: The Lawson Wilkins Pediatric Endocrine Society Lilly Fellowship Award; Contract grant sponsor: Eli Lilly \& Co.; Contract grant sponsor: Pharmacia-Upjohn.

\section{Literature Cited}

Agarwal C, Lambert A, Chandraratna RA, Rorke EA, Eckert RL. Vitamin D regulates human ectocervical epithelial cell proliferation and insulin-like growth factor binding protein-3 level. Biol Reprod. 1999; 60:567-572. [PubMed: 10026100]

Andress DL, Birnbaum RS. Human osteoblast-derived insulinlike growth factor (IGF) binding protein-5 stimulates osteoblast mitogenesis and potentiates IGF action. J Biol Chem. 1992; 267:22467-22472. [PubMed: 1385400]

Angelloz-Nicoud P, Binoux M. Autocrine regulation of cell proliferation by the insulin-like growth factor (IGF) and IGF binding protein-3 protease system in a human prostate carcinoma cell line (PC-3). Endocrinology. 1995; 136:5485-5492. [PubMed: 7588299]

Angelloz-Nicoud P, Harel L, Binoux M. Recombinant human insulin-like growth factor (IGF) binding protein-3 stimulates prostate carcinoma cell proliferation via an IGF-dependent mechanism. Role of serine proteases. Growth Regul. 1996; 6:130-136. [PubMed: 8894645]

Arany E, Afford S, Strain AJ, Winwood PJ, Arthur MJ, Hill DJ. Differential cellular synthesis of insulin-like growth factor binding protein 1 and IGFBP-3 within human liver. J Clin Endocrinol Metab. 1994; 79:1871-1876. [PubMed: 7527416]

Baker J, Liu JP, Robertson EJ, Efstratiadis A. Role of insulinlike growth factors in embryonic and postnatl growth. Cell. 1993; 75:73-82. [PubMed: 8402902] 
Ballard FJ, Knowles SE, Walton PE, Edson K, Owens PC, Mohler MA, Ferraiolo BL. Plasma clearance and tissue distribution of labelled insulin-like growth factor-I (IGF-I), IGF II and des(13)IGF-I in rats. J Endocrinol. 1991; 128:197-204. [PubMed: 2005410]

Barreca A, Artini PG, Cesarone A, Arvigo M, D'Ambrogio G, Genazzani AR, Giordano G, Minuto M. Interrelationships between follicle stimulating hormone and the growth hormone-insulin-like growth factor-IGF-binding proteins axes in human granulosa cells in culture. J Endocrinol Invest. 1996; 19:35-42. [PubMed: 8851690]

Barzilay J, Heatley GJ, Cushing GW. Benign and malignant tumors in patients with acromegaly. Arch Intern Med. 1991; 151:1629-1632. [PubMed: 1678593]

Baxter RC. Insulin-like growth factor binding proteins in the human circulation, a review. Horm Res. 1994; 42:140-144. [PubMed: 7532612]

Baxter RC, Daughaday WH. Impaired formation of the ternary insulin-like growth factor-binding protein complex in patients with hypoglycemia due to nonislet cell tumors. J Clin Endocrinol Metab. 1991; 73:696-702. [PubMed: 1716259]

Baxter RC, Saunders H. Radioimmunoassay of insulin-like growth factor-binding protein-6 in human serum and other body fluids. J Endocrinol. 1992; 134:133-139. [PubMed: 1380056]

Blakesley VA, Koval AP, Stannard BS, Scrimgeour A, LeRoith D. Replacement of tyrosine 1251 in the carboxyl terminus of the insulin-like growth factor-I receptor disrupts the actin cytoskeleton and inhibits proliferation and anchorage-independent growth. J Biol Chem. 1998; 273:1841118422. [PubMed: 9660809]

Blat C, Villaudy J, Binoux M. In vivo proteolysis of serum IGFBP-3 results in increased availability of IGF to target cells. J Clin Invest. 1994; 93:2286-2290. [PubMed: 7514194]

Booth BA, Boes M, Dake BL, Bar RS. Isolation and characterization of plasmin-generated bioactive fragments of IGFBP-3. Am J Physiol. 1999; 276:E450-454. [PubMed: 10070009]

Buckbinder L, Talbott R, Velasco-Miguel S, Takenaka I, Faha B, Seizinger BR, Kley N. Induction of the growth inhibitor IGF-binding protein-3 by p53. Nature. 1995; 377:646-649. [PubMed: 7566179]

Chan JM, Stampfer MJ, Giovannucci E, Gann PH, Ma J, Wilkinson P, Hennekens CH, Pollack M. Plasma insulin-like growth factor-I and prostate cancer risk: a prospective study. Science. 1998; 279:563-566. [PubMed: 9438850]

Chen H, Yan GC, Gishizky ML. Identification of structural characteristics that contribute to a difference in antiapoptotic function between human insulin and insulin-like growth factor-I receptors. Cell Growth Differ. 1998; 9:939-947. [PubMed: 9831246]

Chin E, Zhou J, Dai J, Baxter RC, Bondy CA. Cellular localization of gene expression for components of the IGF ternary complex. Endocrinology. 1994; 134:2498-2504. [PubMed: 7515002]

Clemmons DR, Cascieri MA, Camacho-Hubner C, McCusker RH, Bayne ML. Discrete alterations of the IGF-I molecule which alter its affinity for IGF binding proteins result in changes in bioactivity. J Biol Chem. 1990; 265:12210-12216. [PubMed: 1695626]

Cohen P. Serum insulin-like growth factor-I levels and prostate cancer risk-interpreting the evidence. J Natl Cancer Inst. 1998; 90:876-878. [PubMed: 9637133]

Cohen P, Graves HC, Peehl DM, Kamarei M, Giudice LC, Rosenfeld RG. Prostate-specific antigen (PSA) is an insulin-like growth factor binding protein-3 protease found in seminal plasma. J Clin Endocrinol Metab. 1992; 75:1046-1053. [PubMed: 1383255]

Cohen P, Peehl DM, Stamey TA, Wilson KF, Clemmons DR, Rosenfeld RG. Elevated levels of insulin-like growth factor binding protein-2 in the serum of prostate cancer patients. J Clin Endocrinol Metab. 1993a; 76:1031-1035. [PubMed: 7682560]

Cohen P, Lamson G, Okajima T, Rosenfeld RG. Transfection of the human insulin-like growth factor binding protein-3 gene into Balb/c fibroblasts inhibits cellular growth. Mol Endocrinol. 1993b; 7:380-386. [PubMed: 7683373]

Cohen P, Peehl DM, Graves HC, Rosenfeld RG. Biological effects of prostate specific antigen as an insulin-like growth factor binding protein-3 protease. J Endocrinol. 1994; 142:407-415. [PubMed: 7525824]

Cohen, P.; Rosenfeld, RG. The IGF axis In: Rosenbloom AL, editor Human growth hormone, basic and scientific aspects. Boca Raton, FL: CRC Press; 1995. p. 43-58. 
Colao A, Marzullo P, Speza S, Ferone D, Giaccio A, Cerbone G, Pivonello R, di Somma C, Lombardi G. Effect of growth hormone $(\mathrm{GH})$ and of insulin-like growth factor I on prostate diseases: an ultrasonographic and endocrine study in acromegaly, GH deficiency, and healthy subjects. J Clin Endocrinol Metab. 1999; 84:1986-1991. [PubMed: 10372698]

Conover, CA.; Clarkson, JT.; Durham, SK.; Bale, LK. Cellular actions of insulin-like growth factor binding protein-3. In: LeRoith, D.; Raizada, MK., editors. Current directions in insulin-like growth factor research. New York: Plenum Press; 1993. p. 255-265.

Conover C, DeLeon DD. Acid activated insulin-like growth factor binding protein-3 proteolysis in normal and transformed cells. Role of cathepsin D. J Biol Chem. 1994b; 2691:7076-7080. [PubMed: 7510281]

Conover C, Perry J, Tindall D. Endogenous cathepsin-D-mediated hydrolysis of insulin-like growth factor-binding proteins in cultured human prostatic carcinoma cells. J Clin Endocrinol Metab. 1995; 80:987-993. [PubMed: 7533776]

Conover CA, Powell DR. Insulin-like growth factor (IGF)-binding protein-3 blocks IGF-I-induced receptor down-regulation and cell desensitization in cultured bovine fibroblasts. Endocrinology. 1991; 129:710-716. [PubMed: 1713161]

D'Ambrosio C, Ferber A, Resnicoff M, Baserga R. A soluble insulin-like growth factor I receptor that induces apoptosis of tumor cells in vivo and inhibits tumorigenesis. Cancer Res. 1996; 56:40134020. [PubMed: 8752172]

D'Ambrosio C, Valentinis B, Prisco M, Reiss K, Rubini M, Baserga R. Protective effect of the insulinlike growth factor I receptor on apoptosis induced by okadaic acid. Cancer Res. 1997; 57:32643271. [PubMed: 9242459]

DeMellow JSM, Baxter RC. Growth hormone-dependent insulin-like growth factor (IGF) binding protein both inhibits and potentiates IGF-I stimulated DNA synthesis in human skin fibroblasts. Biochem Biophys Res Commun. 1988; 156:199-204. [PubMed: 2972283]

Dews M, Nishimoto I, Baserga R. IGF-I receptor protection from apoptosis in cells lacking the IRS proteins. Recept Signal Transduc. 1997; 7:231-240.

Doglio A, Dani C, Fredrikson G, Grimaldi P, Ailhaud G. Acute regulation of insulin-like growth factor-I gene expression by growth hormone during adipose cell differentiation. EMBO J. 1987; 6:4011-4016. [PubMed: 3443099]

Donnelly MJ, Holly JM. The role of IGFBP-3 in the regulation of IGFBP-4 proteolysis. J Endocrinol. 1996; 149:R1-R7. [PubMed: 8691093]

Dunn SE, kari FW, Franch J, Leininger JR, Travlos G, Wilson R, Barrett JC. Dietary restriction reduces insulin-like growth factor-I levels, which modulates apoptosis, cell proliferation and tumor progression in p53-deficient mice. Cancer Res. 1997; 57:4667-672. [PubMed: 9354418]

Durham SK, Suwanichkul A, Hayes JD, Herington AC, Powell DR, Campbell PG. The heparinbinding domain of insulin-like growth factor binding protein (IGFBP)-3 increases susceptibility of IGFBP-3 to proteolysis. Horm Metab Res. 1999; 31:216-225. [PubMed: 10226805]

Edmondson SR, Murashita MM, Russo VC, Wraight CJ, Werther GA. Expression of insulin-like growth factor binding protein-3 (IGFBP-3) in human keratinocytes is regulated by EGF and TGFbeta1. J Cell Physiol. 1999; 179:201-207. [PubMed: 10199559]

Elis MJ, Leav BA, Yang Z, Rasmussen A, Pearce A, Zweibel JA, Lippman ME, Cullen KJ. Affinity for insulin-like growth factor-II (IGF-II) receptor inhibits autocrine IGF-II activity in MCF-7 breast cancer cells. Molec Endocrinol. 1996; 10:286-297. [PubMed: 8833657]

Erickson, GF.; Kubo, T.; Li, D.; Kim, H.; Shimasaki, S. The IGF system in the ovary. In: Takano, K.; Hizuka, N.; Takahashi, SI., editors. Molecular mechanisms to regulate the activities of insulinlike growth factors. Amsterdam: Elsevier Science B.V; 1998. p. 185-193.

Erondu NE, Dake BL, Moser DR, Lin M, Boes M, Bar RS. Regulation of endothelial IGFBP-3 synthesis and secretion by IGF-I and TGF-beta. Growth Regul. 1996; 6:1-9. [PubMed: 8717444]

Erondu NE, Nwankwo J, Zhong Y, Boes M, Dake B, Bar RS. Transcriptional and posttranscriptional regulation of insulin-like growth factor binding protein-3 by cyclic adenosine $3^{\prime}, 5^{\prime}-$

monophosphate: messenger RNA stabilization is accompanied by decreased binding of a $42-\mathrm{kDa}$ protein to a uridine-rich domain in the $3^{\prime}$-untranslated region. Mol Endocrinol. 1999; 13:495-504. [PubMed: 10077006] 
Esposito DL, Blakelsey VA, Koval AP, Scrimgeour AG, LeRoith D. Tyrosine residues in the Cterminal domain of the insulin-like growth factor-I receptor mediate mitogenic and tumorigenic signals. Endocrinology. 1997; 138:979-2988.

Ezzat S, Melmed S. Clinical review 18: are patients with acromegaly at increased risk for neoplasia? J Clin Endocrinol Metab. 1991; 72:245-249. [PubMed: 1991795]

Ferry RJ Jr, Katz LE, Grimberg A, Cohen P, Weinzimer SA. Cellular actions of insulin-like growth factor-binding proteins. Horm Metab Res. 1999; 31:192-202. [PubMed: 10226802]

Fowlkes JL, Enghild JJ, Suzuki K, Nagase H. Matrix metalloproteinases degrade insulin-like growth factor binding protein-3 in dermal fibroblast cultures. J Biol Chem. 1994a; 269:742-746.

Fowlkes JL, Suzuki K, Nagase H, Thrailkill KM. Proteolysis of insulin-like growth factor binding protein-3 during rat pregnancy: a role for matrix metalloproteinases. Endocrinology. 1994b; 135:2810-2813. [PubMed: 7527335]

Fowlkes JL, Thrailkill KM, George-Nascimento C, Rosenberg CK, Serra DM. Heparin-binding, highly basic regions within the thyroglobulin type-1 repeat of insulin-like growth factor (IGF)-binding proteins (IGFBPs) -3, -5, and -6 inhibit IGFBP-4 degradation. Endocrinology. 1997; 138:22802285. [PubMed: 9165012]

Friedlander P, Haupt Y, Prives C, Oren M. A mutant p53 gene that discriminates between p53responsive genes cannot induce apoptosis. Mol Cell Biol. 1996; 16:4961-4971. [PubMed: 8756655]

Grimberg A, Cohen P. Growth hormone and prostate cancer: guilty by association? J Endocrinol Invest. 1999; 22:64-73. [PubMed: 10442574]

Grimberg, A.; Liu, B.; Castorino, J.; El-Deiry, W.; Cohen, P. p53 induces insulin-like growth factor binding protein (IGFBP)-3 and apoptosis in two neoplastic cell models. Program \& Abstracts of the 81st Annual Meeting of The Endocrine Society; San Diego CA. Bethesda, MD: The Endocrine Society; 1999. p. 167

Grimberg, A.; Rajah, R.; Zhao, H.; Cohen, P. The prostatic IGF system: new levels of complexity. In: Takano, K.; Hizuka, N.; Takahashi, SI., editors. Molecular mechanisms to regulate the activities of insulin-like growth factors. Amsterdam: Elsevier Science B.V; 1998. p. 205-213.

Gucev ZS, Oh Y, Kelley KM, Rosenfeld RG. Insulin-like growth factor binding protein 3 mediaties retinoic acid- and transforming growth factor $\beta 2$-induced growth inhibition in human breast cancer cells. Cancer Res. 1996; 56:1545-1550. [PubMed: 8603400]

Guler HP, Zapf J, Schmid C, Froesch ER. Insulin-like growth factors I and II in healthy man. Estimations of half-lives and production rates. Acta Endocrinol. 1989; 121:753-758. [PubMed: 2558477]

Han GR, Dohi DF, Lee HY, Rajah R, Walsh GL, Hong WK, Cohen P, Kurie JM. All-trans-retinoic acid increases transforming growth factor-beta2 and insulin-like growth factor binding protein-3 expression through a retinoic acid receptor-alpha-dependent signaling pathway. J Biol Chem. 1997; 272:13711-13716. [PubMed: 9153223]

Ho PJ, Baxter RC. Insulin-like growth factor-binding protein-2 in patients with prostate carcinoma and benign prostatic hyperplasia. Clin Endocrinol. 1997; 46:333-342.

Hodgkinson S, Fowke P, Al Somai N, McQuoid M. Proteins in tissue extracts which bind insulin-like growth factor binding protein-3 (IGFBP-3). J Endocrinol. 1995; 145:R1-R6. [PubMed: 7541067]

Hongo A, D'Ambrosio C, Miura M, Morrione A, Baserga R. Mutational analysis of the mitogenic and transforming activities of the insulin-like growth factor I receptor. Oncogene. 1996; 12:12311238. [PubMed: 8649825]

Huynh H, Yang YF, Pollak M. Estradiol and antiestrogens regulate a growth inhibitory insulin-like growth factor binding protein 3 autocrine loop in human breast cancer cells. J Biol Chem. 1996; 271:1016-1021. [PubMed: 8557625]

Jaques G, Noll K, Wegmann B, Witten S, Kogan E, Radulescu RT, Havemann K. Nuclear localization of insulin-like growth factor binding protein 3 in a lung cancer cell line. Endocrinology. 1997; 138:1767-1770. [PubMed: 9075742]

Jones JI, Gockerman A, Busby WH Jr, Camacho-Hubner C, Clemmons DR. Extracellular matrix contains insulin-like growth factor binding protein-5: potentiation of the effects of IGF-I. J Cell Biol. 1993; 121:679-687. [PubMed: 7683690] 
Kajimoto, Y.; Umayahara, Y.; Fujitani, Y.; Yamasaki, Y.; Hori, M. Involvement of AP-1-like motifs in the IGF-I gene regulation. In: Takano, K.; Hizuka, N.; Takahashi, SI., editors. Molecular mechanisms to regulate the activities of insulin-like growth factors. Amsterdam: Elsevier Science B.V; 1998. p. 31-38.

Kamai Y, Mikawa S, Endo K, Sakai H, Komano T. Regulation of insulin-like growth factor-I expression in mouse preadipocyte Ob1771 cells. J Biol Chem. 1996; 271:9883-9886. [PubMed: 8626620]

Kanety H, Madjar Y, Dagan Y, Levi J, Papa MZ, Pariente C, Goldwasser B, Karasik A. Serum insulinlike growth factor-binding protein-2 (IGFBP-2) is increased and IGFBP-3 is decreased in patients with prostate cancer: correlation with serum prostate-specific antigen. J Clin Endocrinol Metab. 1993; 77:229-233. [PubMed: 7686915]

Kaplan PJ, Mohan S, Cohen P, Foster BA, Greenberg NM. The insulin-like growth factor axis and prostate cancer: lessons learned from the transgenic adenocarcinoma of mouse prostate (TRAMP) model. Cancer Res. 1999; 59:2203-2209. [PubMed: 10232609]

Karas M, Danilenko M, Fishman D, LeRoith D, Levy J, Sharoni Y. Membrane-associated insulin-like growth factor-binding protein-3 inhibits insulin-like growth factor-I-induced insulin-like growth factor-I receptor signaling in ishikawa endometrial cancer cells. J Biol Chem. 1997; 272:1651416520. [PubMed: 9195961]

Kassem M, Okazaki R, Harris SA, Spelsberg TC, Conover CA, Riggs BL. Estrogen effects on of insulin-like growth factor gene expression in a human osteoblastic cell line with high levels of estrogen receptor. Calcif Tissue Int. 1998; 62:60-66. [PubMed: 9405735]

Klein I, Parveen G, Gavoeler JS, Vanthiel DH. Colonic polyps in patients with acromegaly. Ann Intern Med. 1982; 97:27-30. [PubMed: 7092003]

Koistinen R, Itkonen P, Selenius P, Seppala M. Insulin-like growth factor binding protein-1 inhibits binding of IGF-I on fetal skin fibroblasts but stimulates their DNA synthesis. Biochem Biophys Res Commun. 1990; 173:408-415. [PubMed: 2175183]

Ladas SD, Thalassinos NC, Toannides G, Raptis SA. Does acromegaly really predispose to an increased prevalence of gastrointestinal tumours? Clin Endocrinol (Oxf). 1994; 41:597-601. [PubMed: 7828348]

Lalou C, Lassarre C, Binoux M. A proteolytic fragment of insulin-like growth factor (IGF) binding protein-3 that fails to bind IGFs inhibits the mitogenic effects of IGF-I and insulin. Endocrinology. 1996; 137:3206-3212. [PubMed: 8754741]

Landis SH, Murray T, Bolden S, Wingo PA. Cancer statistics, 1998. CA Cancer J Clin. 1998; 48:6-29. [PubMed: 9449931]

Leal SM, Liu Q, Huang SS, Huang JS. The type V transforming growth factor beta receptor is the putative insulin-like growth factor-binding protein-3 receptor. J Biol Chem. 1997; 272:2057220576. [PubMed: 9252371]

LeRoith, D.; Koval, AP.; Butler, AA.; Yakar, S.; Karas, M.; Stannard, BS.; Blakesley, VA. The insulin-like growth factor-I receptor and cellular signaling: implications for celular proliferation and tumorigenesis. In: Takano, K.; Hizuka, N.; Takahashi, SI., editors. Molecular mechanisms to regulate the activities of insulin-like growth factors. Amsterdam: Elsevier Science B.V; 1998. p. 285-290.

Li YM, Schacher DH, Liu Q, Arkins S, Rebeiz N, McCusker RH Jr, Dantzer R, Kelley KW. Regulation of myeloid growth and differentiation by the insulin-like growth factor I receptor. Endocrinology. 1997; 138:362-368. [PubMed: 8977425]

Liu, B.; Cohen, P. Direct functional interactions between IGFBP-3 and RXR regulate gene expression and cellular apoptosis. Meeting and Exhibit Guide of the 81st Annual Meeting of The Endocrine Society; San Diego CA. Bethesda, MD: The Endocrine Society; 1999. p. A-49

Liu, B.; Gibson, TB.; Collett-Solberg, PF.; Zhao, H.; Cerri, RW.; Mascarhenas, D.; Cohen, P. Type 1a collagen is an IGFBP-3 binding protein. Program \& Abstracts of the 81st Annual Meeting of The Endocrine Society; San Diego CA. Bethesda, MD: The Endocrine Society; 1999. p. 405

Liu JP, Baker J, Perkins AS, Robertson EJ, Efstratiadis A. Mice carrying null mutations of the genes encoding insulin-like growth factor I (Igf-I) and type 1 IGF receptor (Igf1r). Cell. 1993; 75:59-72. [PubMed: 8402901] 
Lowe WL Jr, Adamo M, Werner H, Roberts CT Jr, LeRoith D. Regulation by fasting of rat insulin-like growth factor-I and its receptor: effects on gene expression and binding. J Clin Invest. 1989; 84:619-626. [PubMed: 2547834]

Ludwig RL, Bates S, Vousden KH. Differential activation of target cellular promoters by p53 mutants with impaired apoptotic function. Mol Cell Bio. 1996; 16:4952-4960. [PubMed: 8756654]

Ludwig T, Eggenschweiler J, Fisher P, D'ercole AJ, Davenport ML, Efstratiadis A. Mouse mutants lacking the type 2 IGF receptor (IGF2R) are resuced from perinatal lethality in Igf2 and Igf1r null backgrounds. Dev Biol. 1996; 177:517-535. [PubMed: 8806828]

Ma J, Pollack MN, Giovannucci E, Chan JM, Tao Y, Hennekens CH, Stampfer MJ. Prospective study of colorectal cancer risk in men and plasma levels of insulin-like growth factor (IGF)-I and IGFbinding protein-3. J Natl Cancer Inst. 1999; 91:620-625. [PubMed: 10203281]

MacDonald RG, Schaffer BS, Kang IJ, Hong SM, Kim EJ, Park JH. Growth inhibition and differentiation of the human colon carcinoma cell line, Caco-2, by constitutive expression of insulinlike growth factor binding protein-3. J Gastroenterol Hepatol. 1999; 14:72-78. [PubMed: 10029281]

Mannhardt B, Weinzimer SA, Cohen P, Jansen-Durr P, Zwerschke W. The human papillomavirus E7 oncoprotein binds and inactivates the growth inhibitory IGF-binding protein-3. Nat Cell Biol. 1999 submitted.

Mantzoros CS, Tzonou A, Signorello LB, Stampfer A, Trichopoulos D, Adami HO. Insulin-like growth factor 1 in relation to prostate cancer and benign prostatic hyperplasia. Br J Cancer. 1997; 76:1115-1118. [PubMed: 9365156]

McCarthy TL, Centrella M, Canalis E. Cyclic AMP induces insulin-like growth factor 1synthesis in osteoblast-enriched cultures. J Biol Chem. 1990; 265:15353-15356. [PubMed: 1697590]

Neumann GM, Bach LA. The N-terminal disulfide linkages of human insulin-like growth factorbinding protein-6 (hIGFBP-6) and hIGFBP-1 are different as determined by mass spectrometry. $\mathrm{J}$ Biol Chem. 1999; 274:14587-14594. [PubMed: 10329650]

Noll, K.; Hochscheid, R.; Wegmann, B., et al. Hints for the nuclear import and location of insulin-like growth factor binding protein-3 in lung cancer cell lines. Program \& Abstracts of the 4th International Symposium on Insulin-like Growth Factors; Tokyo, Japan. Foundation for Growth Science; 1997. p. 139

Nunn S, Peehl DM, Cohen P. Acid-activated insulin-like growth factor binding protein protease activity of cathepsin D in normal and malignant prostatic epithelial cells and seminal plasma. $\mathbf{J}$ Cell Physiol. 1997; 171:196-204. [PubMed: 9130467]

O'Connor R, Kauffmann-Zeh A, Liu Y, Lehar S, Evan GI, Baserga R, Blattler WA. Identification of domains of the insulin-like growth factor-I receptor that are required for protection from apoptosis. Mol Cell Biol. 1997; 17:427-435. [PubMed: 8972223]

Oh Y, Müller HL, Pham H, Rosenfeld RG. Demonstration of receptors for insulin-like growth factor binding protein-3 on Hs578T human breast cancer cells. J Biol Chem. 1993a; 268:26045-26048. [PubMed: 7504671]

Oh Y, Müller HL, Lamson G, Rosenfeld RG. Insulin-like growth factor (IGF)-independent action of IGF-binding protein-3 in Hs578T human breast cancer cells. Cell surface binding and growth inhibition. J Biol Chem. 1993b; 268:14964-14971. [PubMed: 7686909]

Okabe E, Kajihara J, Usami Y, Hirano K. The cleavage site specificity of human prostate specific antigen for insulin-like growth factor binding protein-3. FEBS Lett. 1999; 19:87-90. [PubMed: 10218588]

Okazaki R, Durham SK, Riggs BL, Conover CA. Transforming growth factor-beta and forskolin increase all classes of insulin-like growth factor-I transcripts in normal human osteoblast-like cells. Biochem Biophys Res Commun. 1995; 207:963-970. [PubMed: 7864902]

Olivecrona H, Hilding A, Ekstrom C, Barle H, Nyberg B, Moller C, Delhanty PJ, Baxter RC, Angelin B, Ekstrom TJ, Tally M. Acute and short-term effects of growth hormone on insulin-like growth factors and their binding proteins: serum levels and hepatic messenger ribonucleic acid responses in humans. J Clin Endocrinol Metab. 1999; 84:553-560. [PubMed: 10022415]

Olney RC, Tsuchiya K, Wilson DM, Mohtai M, Maloney WJ, Schurman DJ, Smith RL. Chondrocytes from osteoarthritic cartilage have increased expression of insulin-like growth factor I (IGF-I) and 
IGF-binding protein-3 (IGFBP-3) and -5, but not IGF-II or IGFBP-4. J Clin Endocrinol Metab. 1996; 81:1096-1103. [PubMed: 8772582]

Parisot JP, Hu XF, DeLuise M, Zalcberg JR. Altered expression of the IGF-1 receptor in a tamoxifenresistant human breast cancer cell line. Br J Cancer. 1999; 79:693-700. [PubMed: 10070856]

Prisco M, Hongo A, Rizzo MG, Sacchi A, Baserga R. The insulin-like growth factor I receptor as a physiologically relevant target of p53 in apoptosis caused by interleukin-3 withdrawal. Molec Cell Biol. 1997; 17:1084-1092. [PubMed: 9032235]

Rajah R, Bhala A, Nunn SE, Peehl DM, Cohen P. 7S nerve growth factor is an insulin-like growth factor binding protein protease. Endocrinology. 1996a; 137:2676-2682. [PubMed: 8770886]

Rajah R, Katz L, Nunn S, Solberg P, Beers T, Cohen P. Insulin-like growth factor binding protein proteases: functional regulators of cell growth. Prog Growth Factor Res. 1996b; 6:273-284. [PubMed: 8817670]

Rajah R, Valentis B, Cohen P. Insulin-like growth factor (IGF)-binding protein-3 induces apoptosis and mediates the effects of transforming growth factor- $\beta 1$ on programmed cell death via a $\mathrm{p} 53$ and IGF-independent mechanism. J Biol Chem. 1997; 272:12181-12188. [PubMed: 9115291]

Resnicoff M, Abraham D, Yutanawioonchai W, Rotman HL, Kajstura J, Rubin R, Zoltick P, Baserga R. The insulin-like growth factor I receptor protects tumor cells from apoptosis in vivo. Cancer Res. 1995; 55:2463-2469. [PubMed: 7758000]

Rinderknecht E, Humbel RE. The amino acid sequence of human insulin-like growth factor I and its structural homology with proinsulin. J Biol Chem. 1978a; 253:2769-2776. [PubMed: 632300]

Rinderknecht E, Humbel RE. Primary structure of human insulin-like growth factor II. FEBS Lett. 1978b; 89:283-286. [PubMed: 658418]

Ron E, Gridley G, Hrubec Z, Page W, Arora S, Fraumeni JF Jr. Acromegaly and gastrointestinal cancer. Cancer. 1991; 68:1673-1677. erratum in Cancer 69:549, 1992. [PubMed: 1913507]

Rotwein P. Structure, evolution, expression and regulation of insulin-like growth factors I and II. Growth Factors. 1991; 5:3-18. [PubMed: 1772660]

Salahifar H, Baxter RC, Martin JL. Insulin-like growth factor binding protein (IGFBP)-3 protease activity secreted by MCF-7 breast cancer cells: inhibition by IGFs does not require IGF-IGFBP interaction. Endocrinology. 1997; 138:1683-1690. [PubMed: 9075731]

Schedlich LJ, Young TF, Firth SM, Baxter RC. Insulin-like growth factor-binding protein (IGFBP)-3 and IGFBP-5 share a common nuclear transport pathway in T47D human breast carcinoma cells. J Biol Chem. 1998; 273:18347-18352. [PubMed: 9660801]

Sell C, Rubini M, Rubin R, Liu JP, Efstratiadis A, Baserga R. Simian virus 40 large tumor antigen is unable to transform mouse embryonic fibroblasts lacking type I insulin-like growth factor receptor. Proc Natl Acad Scien USA. 1993; 90:11217-11221.

Shang Y, Baumrucker CR, Green MH. Signal relay by retinoic acid receptors alpha and beta in the retinoic acid-induced expression of insulin-like growth factor-binding protein-3 in breast cancer cells. J Biol Chem. 1999; 18:18005-18010. [PubMed: 10364250]

Shen L, Dean NM, Glazer RI. Induction of p53-dependent, insulin-like growth factor-binding protein-3-mediated apoptosis in glioblastoma mutliforme cells by a protein kinase $\mathrm{Ca}$ antisense oligonucleotide. Molec Pharmacol. 1999; 55:396-402. [PubMed: 9927633]

Stoving RK, Flyvbjerg A, Frystyk J, Fisker S, Hangaard J, Hansen-Nord M, Hagen C. Low serum levels of free and total insulinlike growth factor I (IGF-I) in patients with anorexia nervosa are not associated with increased IGF-binding protein-3 proteolysis. J Clin Endocrinol Metab. 1999; 84:1346-1350. [PubMed: 10199777]

Strauss DS, Takemoto CD. Effect of dietary protein deprivation on insulin-like growth factor (IGF)-I and -II, IGF binding protein-2, and serum albumin gene expression in rat. Endcorinol. 1990; 127:1849-1860.

Strauss DS, Takemoto CD. Specific decrease in liver insulin-like growth factor-I and brain insulin-like growth factor-II gene expression in energy-restricted rats. J Nutrit. 1991; 121:1279-1286. [PubMed: 1713624]

Swolin D, Brantsing C, Matejka G, Ohlsson C. Cortisol decreases IGF-I mRNA levels in human osteoblast-like cells. J Endocrinol. 1996; 149:397-403. [PubMed: 8691098] 
Troisi RJ, Freedman AN, Devesa SS. Incidence of colorectal carcinoma in the U.S.: an update of trends by gender, race, age, subsite, and stage, 1975-1994. Cancer. 1999; 85:1670-1676. [PubMed: 10223559]

Ullrich A, Gray A, Tam AW, Yang-Feng T, Tsubokawa M, Collins C, Henzel W, Le Bon T, Kathuria $\mathrm{S}$, Chen E, et al. Insulin-like growth factor I receptor primary structure: comparison with insulin receptor suggests structural determinants that define functional specificity. EMBO J. 1986; 5:2503-2512. [PubMed: 2877871]

Valentinis B, Bhala A, DeAngelis T, Baserga R, Cohen P. The human insulin-like growth factor (IGF) binding protein-3 inhibits the growth of fibroblasts with a targeted disruption of the IGF-I receptor gene. Mol Endocrinol. 1995; 9:361-367. [PubMed: 7539889]

Weinzimer, SA.; Gibson, TB.; Collett-Solberg, PF.; Zhao, H.; Khare, A.; Cohen, P. Transferrin is an IGFBP-3 binding protein. Program \& Abstracts of the 81st Annual Meeting of The Endocrine Society; San Diego CA. Bethesda, MD: The Endocrine Society; 1999. p. 83

Wingo PA, Ries LA, Giovino GA, Miller DS, Rosenberg HM, Shopland DR, Thun MJ, Edwards BK. Annual report to the nation on the status of cancer, 1973-1996, with a special section on lung cancer and tobacco smoking. J Natl Cancer Inst. 1999; 91:675-690. [PubMed: 10218505]

Wolk A, Mantzoros CS, Andersson SO, Bergstrom R, Signorello LB, Lagiou P, Adami HO, Trichopoulos D. Insulin-like growth factor 1 and prostate cancer risk: a population-based, casecontrol study. J Natl Cancer Inst. 1998; 90:911-915. [PubMed: 9637140]

Wraight, CJ.; Liepe, IJ.; Werther, GA. Intracellular localisation of insulin-like growth factor binding protein-3 during mitosis in human keratinocytes. Program \& Abstracts of the 4th International Symposium on Insulin-like Growth Factors; Tokyo, Japan. Tokyo, Japan: Foundation for Growth Science; 1997. p. 139

Wraight CJ, Liepe IJ, White PJ, Hibbs AR, Werther GA. Intranuclear localization of insulin-like growth factor binding protein-3 (IGFBP-3) during cell division in human keratinocytes. J Invest Dermatol. 1998; 111:239-242. [PubMed: 9699724]

$\mathrm{Xu}, \mathrm{W}$.; Murphy, LJ. Interaction of IGFBP-3 with latent transforming growth factor- $\beta$ binding protein-1 identified using the yeast two-hybrid system. Program \& Abstracts of the 80th Annual Meeting of The Endocrine Society; New Orleans LA. Bethesda, MD: The Endocrine Society; 1998. p. 313

Yamanaka Y, Fowlkes JL, Wilson EM, Rosenfeld RG, Oh Y. Characterization of insulin-like growth factor binding protein-3 (IGFBP-3) binding to human breast cancer cells: kinetics of IGFBP-3 binding and identification of receptor binding domain on the IGFBP-3 molecule. Endocrinology. 1999; 140:1319-1328. [PubMed: 10067859]

Yang YWH, Yanagishita M, Rechler MM. Heparin inhibition of insulin-like growth factor binding protein-3 (IGFBP-3) binding to human fibroblasts and rat glioma cells: role of heparan sulfate proteoglycans. Endocrinology. 1996; 137:4363-4371. [PubMed: 8828497]

Yu H, Spitz MR, Mistry J, Gu J, Hong WK, Wu X. Plasma levels of insulin-like growth factor-I and lung cancer risk: a case-control analysis. J Natl Cancer Inst. 1999; 91:151-156. [PubMed: 9923856]

Zadeh SM, Binoux M. The 16-kDa proteolytic fragment of insulin-like growth factor (IGF) binding protein-3 inhibits the mitogenic action of fibroblast growth factor on mouse fibroblasts with a targeted disruption of the type 1 IGF receptor gene. Endocrinology. 1997; 138:3069-3072. [PubMed: 9202255]

Zheng B, Clarke JB, Busby WH, Duan C, Clemmons DR. Insulin-like growth factor-binding protein-5 is cleaved by physiological concentrations of thrombin. Endocrinology. 1998; 139:1708-1714. [PubMed: 9528953] 

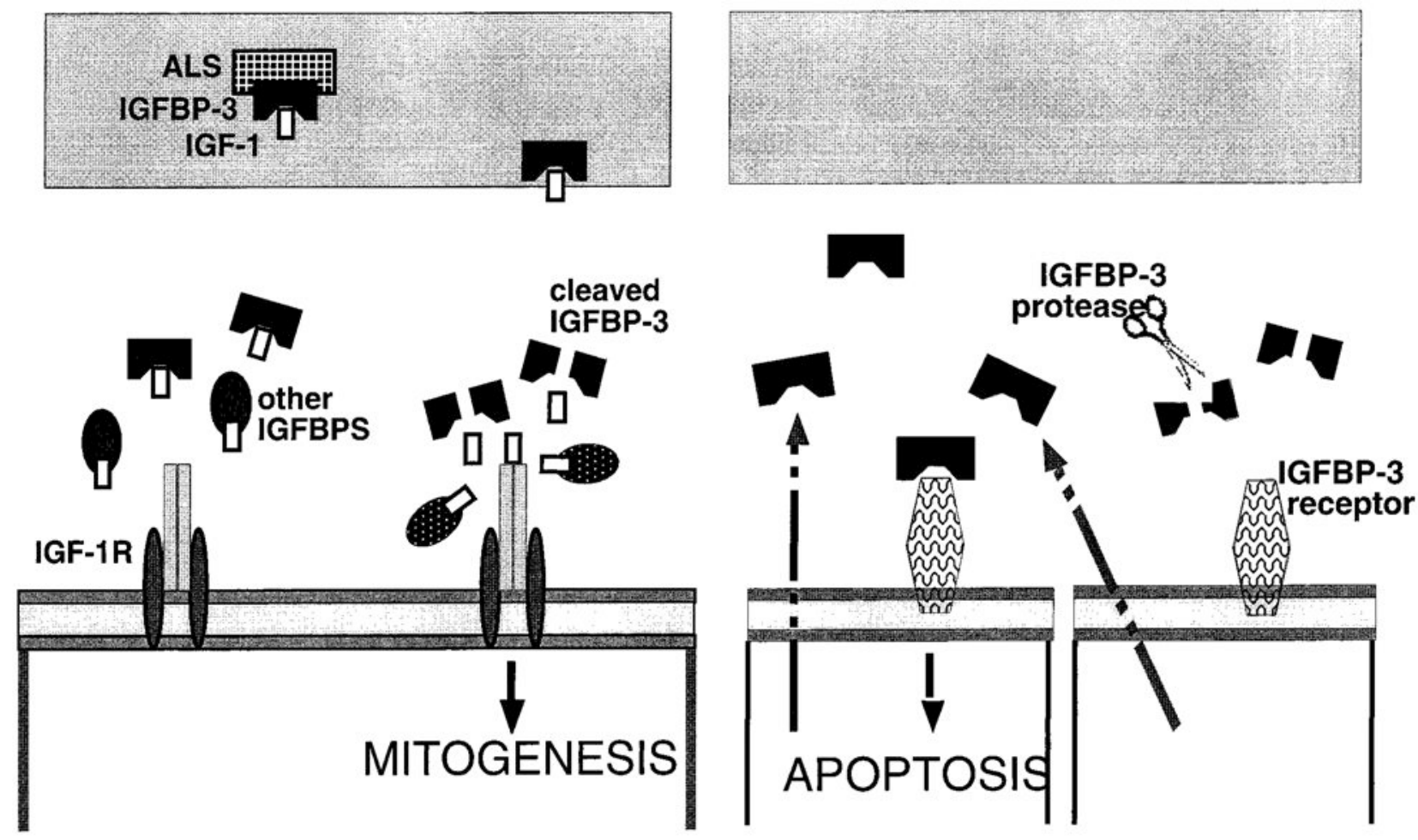

(A)

(B)

Fig. 1.

Insulin-like growth factor-binding protein (IGFBP) functions. A: Modulating IGF actions. IGFBP-3, as part of the 150-kDa complex, carries insulin-like growth factors (IGFs) in the circulation and traffics them to the target tissues. At the target cells, IGFBPs can prevent insulin-like growth factor type 1 receptors (IGF-1R) down-regulation by sequestering the IGFs, as shown on the left. When cleaved by IGFBP proteases, the IGFBPs release free IGF to bind to the IGF-1R and stimulate mitogenesis, as shown on the right. B: IGF-independent actions. IGFBP-3, secreted in an autocrine or para-crine manner, can bind to its cell surface receptor and induce apopto-sis in an IGF-independent fashion. IGFBP proteases can cleave the IGFBPs and thereby reduce or completely eliminate this effect. 
Table 1

IGF axis perturbations that can contribute to carcinogenesis

I. Increased IGF/IGF-1R activity.

A. Elevated IGF levels.

1. systemic.

2. autocrine/paracrine.

B. Enhanced IGF-1R function.

1. receptor number.

2. receptor activity.

3. stimulation by IGF.

a. modulated by IGFBPs.
1. systemic.
2. autocrine/paracrine.

b. modulated by IGFBP proteases.

II. Decreased IGF-independent growth inhibition by IGFBPs.

A. Diminished IGFBP levels.
1. systemic.
2. autocrine/paracrine.
3. reduced induction by IGFBP-regulators.
4. augmented proteolysis.

B. Impaired IGFBP function.

1. disrupted interactions with cell surface receptors or association proteins.

2. ineffective nuclear localization. 